\title{
Yes to ski helmets, but buyer beware
}

$\mathrm{N}$ ova Scotia passed legislation on Dec. 15, 2011, requiring all skiers and snowboarders - children and adults - to wear a helmet. This likely constitutes the world's toughest such rules and is laudable from a public health perspective, but there's just one problem.

How good are the helmets? The fact is that, to protect their noggins, Canadian skiers and snowboarders might as well be using a toque as some of the helmets being sold. That's according to an expert at the Canadian Standards Association (CSA). ${ }^{1}$ The CSA consulted with helmet manufacturers, resort owners, skiing groups and other stakeholders to come up with higher standards for made-in-Canada ski and snowboard helmets. Those standards were released back in 2009 but have yet to be met by any manufacturer. Why not is anyone's guess. It could be that Canada's relatively small market is deterring those who have to adhere to a bottom line. But undoubtedly, the lack of demand for CSA-approved helmets is a factor.

So what are Canadians buying? Helmets that meet European or US standards or poor quality knock-offs. ${ }^{1}$ And while the CSA generally prefers to save time and money by piggybacking on other jurisdictions' standards, in this case it decided that those standards weren't stringent enough and decided to raise the bar. ${ }^{1}$ The helmets that meet the new CSA standards would withstand multiple impacts (up to three impacts on a single site) and feature foam that is manufactured to accommodate specific head sizes and weights, thus providing optimal protection for a range of impacts.

Helmets are a no-brainer. Traumatic brain injury is the leading cause of death and catastrophic injury among those who ski and snowboard. ${ }^{2}$ An international overview, which included Canada, found that head injuries account for $9 \%$ to $19 \%$ of all injuries sustained during these winter sports. ${ }^{3}$ Most head injuries are concussions (83\%). ${ }^{4}$ Last winter, Canadian skiers and snowboarders sustained 135 serious head injuries. ${ }^{5}$ Although data on risk reduction are nuanced by the fact that those who wear helmets tend to be more cautious, wearing a helmet reduces the risk of head injury by $35 \%$. $^{3}$ Helmet use gained publicity in 2009, when British actress Natasha Richardson died of a head injury following a fall during a skiing lesson at Mont Tremblant, Quebec. She wasn't wearing a helmet.

Nova Scotia's precedent-setting legislation, which comes into effect on Nov. 1, 2012, with fines of up to $\$ 250$, stemmed from concern over the consequences of brain injury and the cost to treat them: roughly $\$ 400000$ annually, according to the government. ${ }^{6}$ But in the absence of CSA-approved helmets, Nova Scotia's Snow Sport Helmet Act, though laudable, is premature.

However, there is a solution. Through the Hazardous Prod- ucts Act (now the Canadian Consumer Product Safety Act), Health Canada has ruled that all hockey helmets advertised, imported or sold in Canada must meet the CSA standards. Oddly, they have not done the same for ski and snowboard helmets. And it's not because of a lack of awareness. Dr. Hedy Fry, member of parliament for Vancouver Centre, has twice introduced a private member's bill calling for helmets for recreational snow sports to be added to the Hazardous Product Act, most recently in February 2011 (Bill C-412).

Some opponents to the legislation argue that it isn't necessary because helmet use is increasing. Data from the Canadian Ski Council's annual National Consumer Profile and Satisfaction Survey indicate that usage in 2010 was $71 \%$, up from $67 \%$ in 2006 . $^{7}$ This is good news, but the fact remains that the quality of these helmets is not up to Canadian standards.

In the absence of helmets that meet Canadian standards, health professionals and public health officials will have difficulty advising Canadians on how to safely enjoy winter sports. Those standards are available. Heads-up federal government, it's high time to establish a regulation so that skiers and snowboarders know that helmets purchased in Canada actually provide adequate protection. Hockey players already know this. Why the double standard when we shoot the double diamond?

\section{Barbara Sibbald BJ}

Deputy Editor, Analysis and Humanities, CMAJ

\section{References}

1. Doug Morton, Director, Health Care and Safety, Canadian Standards Association, Mississauga, Ont.: personal communication, 2011

2. Ackery A, Hagel BE, Provvidenza C, et al. An international review of head and spinal cord injuries in alpine skiing and snowboarding. Inj Prev 2007;13:368-75.

3. Russell K, Christie J, Hagel BE. The effect of helmets on the risk of head and neck injuries among skiers and snowboarders: a meta-analysis. CMAJ 2010;182: $333-40$

4. Sulheim S, Holme I, Ekeland A, et al. Helmet use and risk of head injuries in alpine skiers and snowboarders. JAMA 2006;295:919-24.

5. Canadian Institute for Health Information. More than 5,600 Canadians seriously injured every year from winter activities [media release]. Ottawa $(\mathrm{ON})$ : The Institute; 2012. Available: www.cihi.ca/CIHI-ext-portal/internet/en/document/types +of+care/specialized+services/trauma+and+injuries/release_17jan12?WT.ac=home_ banner_20120117_e (accessed 2012 Jan. 17).

6. Selly C. Nova Scotia's ski-helmet law: preventing a statistically insignificant number of head injuries. National Post 2011 Dec 8. Available: http://fullcomment .nationalpost.com/2011/12/08/chris-selley-nova-scotias-ski-helmet-law-preventing-a -statistically-insignificant-number-of-head-injuries (accessed 2012 Jan 30).

7. Canadian Ski Council. Helmets and ski safety facts and stats: November 2009 Collingwood (ON): The Council; 2009. Available: www.skicanada.org/_assets/files /Helmet\%20Information\%20Nov\%202nd\%20final.pdf (accessed 2012 Jan. 2).

Competing interests: See www.cmaj.ca/site/misc/cmaj_staff.xhtml

Correspondence to: CMAJ editor,pubs@cmaj.ca

CMAJ 2012. DOI:10.1503/cmaj.120144 